\title{
Gene therapy gathers speed in Germany
}

Freiburg, Germany. Overcoming fears of public opposition that now appear to have had little foundation, both federal and state authorities in Germany - and at least one pharmaceutical company - have begun pouring substantial amounts of money into research on the therapeutic use of genes.

At least eight groups are now engaged in gene therapy research. And, as a result of such activity, concern is subsiding that both German scientists and German companies could be left behind in this field by European competitors elsewhere in Europe.

At the beginning of this month, for example, the federal ministry of research and technology (BMFT) announced that it is prepared to spend up to DM60 million (US\$37 million) over the next six years to support trials of gene therapy techniques.

The goal of the programme is to support the development of genetic probes and techniques for transferring genes into the human body in ways that will allow the treatment of diseases such as cancer and AIDS.

The BMFT initiative has been launched at a time when, despite continued widespread public opposition to genetic engineering in general, there has been little specific criticism directed at research on the medical applications of such techniques.

Research in gene therapy is already being supported by Germany's main source of funding for university research, the Deutsches Forschungsgemeinschaft (DFG). In particular, the DFG has provided DM 6,6 million to support a three-year research programme at the University of Freiburg into the molecular and cellular basis of host defence mechanisms against tumours.

One participant in the project is Roland Mertelsmann, a haematologist who was last year given the first - and so far only approval for gene therapy trials in Germany (see Nature, 360, 702; 1992). Mertelsmann chose to use electroporation rather than a viral vector to get the gene into cells because he feared public opposition to the use of viruses.

$\mathrm{He}$ plans to inject a vaccine containing a mixture of inactivated tumour cells and transgenic fibroblasts into which the gene for the immunostimulating cytokine

\section{European Parliament plans 'science summit'}

Brussels. The European Parliament is planning a two-day meeting in Brussels next month, to discuss how science and technology can contribute to the new challenges facing Europe. The meeting, described as a "science summit", will be attended by leading scientists, government science policy officials, and directors of funding agencies, as well as by the chairpersons of the relevant Parliamentary committees. interleukin-2 (IL-2) has been inserted. The goal is to provoke an immunological response to melanoma and its metastases.

The first efforts, however, have been disappointing. The system worked well in mice, activating cytotoxic $T$ cells that went on to select and kill cancer cells. But experiments so far with human cells have been less

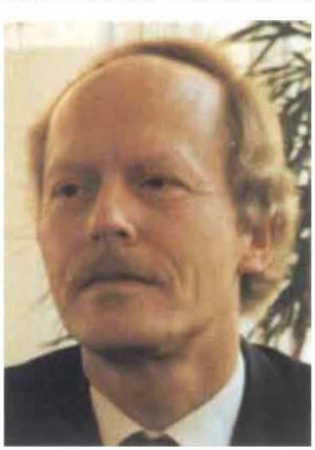

Roland Mertelsmann successful. As a result, no tests have yet been carried out with human patients ( a l though Mertelsmann says that he expects to start vaccinating melanoma patients "within the next few months").

As an alter-

native strategy, Mertelsmann has now teamed up with the German pharmaceutical company Boehringer Ingelheim in a deal that allows him to use company's patented receptor-mediated endocytosis method to treat renal cell carcinoma.

This technique has been developed by Max Birnstiel and Ernst Wagner at the Institute for Molecular Pathology in Vienna, an organization set up in 1985 as a joint venture between Boehringer Ingelheim and Genentech of Cali-

fornia, but now wholly owned by Boehringer.

In addition to Mertels-mann, several other German teams are already planning to use the same transfection method. One, headed by Eva-Bettina Bröcker, director of the skin clinic in Würzburg, hopes to begin experimental treatment next year using IL-2 genes on patients with melanoma.

Two teams in Heidelberg - one at the Medical Polyclinic, the other at the German Cancer Research Centre - are also planning to start gene therapy tests to treat melanoma. Other groups in Germany are planning experiments on the potential use of gene therapy to treat leukaemia and haemophilia, as well as metabolic disturbances such as hypercholesterolaemia.

So far, Boehringer Ingelheim is the only company to have publicly acknowledged its interest in gene therapy research. In addition, the Boehringer Ingelheim Foundation - in a move which its directors claim was entirely independent of the company's interest in the field - has decided to offered half of its grants budget to the University of Mainz to enable the university to set up a group of young scientists working on gene therapy.

Other pharmaceutical companies, many of whom are working with research groups in other countries to avoid Germany's stringent genetic engineering laws, say they are keeping a close eye on developments.

Robert Unterhuber

\section{Ireland seeks advice on research}

Dublin. The Irish government is setting up an independent group to review its science and technology policy following complaints that it has not been taking adequate responsibility for research. But critics are worried that the report may be too narrowly based on the needs of industry.

The review group will be coordinated by the Office of Science and Technology (OST), part of the Department of Enterprise and Employment within the Ministry for Industry and Commerce. According to Michael Fahy of the OST, the group will consist of between ten and 15 individuals, selected from both industry and from the scientific and technical communities.

The group will be asked to provide its recommendations within six months, and the government expects to respond to the report with a white paper (policy document) of its own within a further three months.

Fahy says that the decision to set up a review group reflects the OST's concern that science and technology has no champion in government now that the major research funding agency, Eolas, has been absorbed into a new industrial support body called Forbairt (see Nature 364, 662; 1993).

But a head of steam has been building up all year. Research support groups and academic groups have been putting the government under considerable pressure, complaining that the Ministry of Industry and Commerce, responsible for all governmentsupported non-health research funding, has shown little interest in maintaining a strong basic research base in Ireland.

The Irish Research Scientist's Association (IRSA) says it doubts whether a report originating within the Ministry of Industry and Commerce will provide a wide enough scope for a national science policy. A spokesman for the association, Michael Hopkins from Dublin City University, says that other government departments, such as health, education and agriculture, which are more active in research and have more general interests in science, should be involved.

The IRSA is also concerned that active scientists may not be appointed to the review group. The make-up of the group has not been announced, but Fahy says that the OST does not intend to include representatives of all interested parties.

Alison Abbott 